\title{
THE COMPARISON OF DESCRIPTIVE TEXT WRITING ABILITY USING YOU TUBE DOWNLOADED VIDEO AND SERIAL PICTURES AT THE STUDENTS'OF SMPN 2 METROACADEMIC YEAR 2012/2013 \\ by \\ Eka Bayu Pramanca and Dedi Turmudi \\ Teacher Training and Education Faculty of Muhammadiyah University of Metro \\ Lampung 34111
}

\begin{abstract}
:
This research discusses about how two different techniques affect the students' ability in descriptive text at SMP N 2 Metro. The objectives of this research are (1) to know the difference result of using YouTube Downloaded Video and Serial Pictures media toward students' writing ability in descriptive text and (2) to know which one is more effective of students' writing ability in descriptive text instruction between learning by using YouTube Downloaded Video and Serial Pictures media. The implemented method is quantitative research design in that both researchers use true experimental research design. In this research, experimental and control class pre-test and post test are conducted. It is carried out at the first grade of SMP N 2 Metro in academic year 2012/2013. The population in this research is 7 different classes with total number of 224 students. 2 classes of the total population are taken as the samples; VII.1 students in experimental class and VII.2 students in control class by using cluster random sampling technique. The instruments of the research are tests, treatment and post-test. The data analyzing procedure uses t-test and results the following output. The result of $t_{\text {test }}$ is 3,96 and $t_{\text {table }}$ is 2,06 . It means that $t_{\text {count }}>t_{\text {table }}$ with the criterion of $t_{\text {test }}$ is $H_{a}$ is accepted if $t_{\text {count }}$ $>t_{\text {table. }}$ So, there is any difference result of students' writing ability using YouTube Downloaded Video and Serial Pictures Media. However; Youtube Downloaded Video media is more effective media than Serial Pictures media toward students' writing ability. This research is consistent with the previous result of the studies and thus this technique is recommended to use in writing instruction especially in descriptive text in order that students may feel fun and enjoy during the learning process.
\end{abstract}

Key Words : Descriptive, Serial Pictures, Writing Ability, YouTubedownloaded

\section{Introduction}

The four skills in English as foreign language that the students have to master cover listening, speaking, reading and writing.

Writing is one of the most important parts in syllabus and in teaching of English with certain goals to achieve. One of the goals of teaching writing is that the student can write appropriately and effectively in many kinds of genres. Although the tendency that writing seems to be the most difficult skills is probably provoked by the theory of Audio Lingual Method (ALM) stating that writing is the last skill of productive skills to achieve (Richard and Rodgers, 2001), (Larsen-
Freeman, 2000), this skill appeals to be a good object to research. In the field; however; many teachers take different directions in writing's goal; focus on form, the writers and the readers.

In this regard, both researchers found out (pre survey) that the students' score in writing of descriptive text were still low. The cause of the low score in writing descriptive text was due to their skill in writing was still poor.

The pre-survey conducted before informed that there were 45 students who got score less than 50 and there were just 17 students who got score more than 70 . It means that most students of the first grade of SMP N 
2 Metro still had lack of knowledge of writing descriptive text. This implies that the quality of English language lessons in English writing ability in descriptive text was still low.

The solution of this problem was assumed to be cured by implementing the selected techniques on the basis of the empirical or prior experiments with both proposed techniques. The mentioned techniques are what Brown (2001, p 1-2) means to be as quoted.

Having analyzed of both related literatures, both researchers hoped that the re-use or reimplementation of the chosen techniques, would have a great effect on the students' descriptive writing ability. This makes sense because good technique(s) have to have a good effect on the learners' four skills. According to Harmer (2001) a good teacher has to have specific characteristics as the following descriptions; attractive, making interesting subject, has broad knowledge, and correcting with no blaming, and helping but without mocking(p.1-2.).

Furthermore, Broughton at al.,(2003) proposed the nature of writing skill characterized with possible problems the students will face if the goal of teaching is to make the students to produce fluent, accurate, and appropriate written English. The problems cover mechanical issues with script of English, accuracy, writing style, and developing (p.116).

Consequently, "writing well in a second language would require more and higher cognitive skills to be able to write well" (Magno, 2009, p.5). That is why both researchers refer back to the previous research overview.

The first previous research was conducted by Ahmad (2011) entitled "The Use of Picture Series to Improve Eight Graders' Writing Descriptive Texts at MTs N Babakan Ciledug Cirebon."His preliminary study turned out that the writing ability of the students academic year 2010-2011 of class VIII was still unsatisfactory. It might be caused of that the students had difficulties in generating the ideas, exploring the vocabularies and low motivation in writing activities. Therefore, this research was conducted to solve the students' writing problems. The objective of the study is to improve the students' writing ability.

The findings shows that the picture series is effective to improve the students' writing ability and the students' involvement in the teaching-learning English are quite good. Thus, English teachers are suggested to implement this media in teaching writing.

The second previous research was done by Savitrie (2011)etitled" The Use of Authentic Videos Taken from YouTube in the Teaching of English to the Ninth Graders of SMP Negeri 12 Jember." This research was aimed to investigate how YouTube videos that can be used in an English classroom by answering several research questions

The results of this research shows that videos provided on YouTube are of different categories; materials for teaching English as long as they are suitable with the topic being taught. It was also found that the authentic videos used were chosen based on some important considerations; visualizations or imagery, the language use, the 
relevance of the videos with the topic and content, and the popularity of the content for most of the students (Savirie, 2011).

The result of this study also shows that more than $70 \%$ of the students felt more interested in learning English when the teacher utilized authentic videos in her teaching. They enjoyed the learning activities, and while using videos they felt like they were exposed to the real world where English is used.(Savitrie at. al).

Finally, this research implies that the future researchers will use this technique. This suggestion is addressed due to the fact that the learners need vivid media to make them easy an enjoy in learning English as foreign language (EFL) and thus boosts the teaching Engish.

Besides prior research, some scholars deserve to quote to support the foundation theories. Teaching English as a foreign language (TEFL) in Indonesia often makes the teachers in dilemmatic situation. The learners have to learn English well but the teachers cannot make the students actively involved in the learning process. Consequently, those teachers have to become more creative and innovative in their teaching in order to make the students feel interested in learning English, as well as the teaching strategy in writing (Peha, 2003). Accordingly, teachers are highly advised to expand their knowledge related to the development of English teaching by using media or any technology of Media Education in Youtube (2013).

One of the most important developments with regard to English teaching is the use of technology or media such as internet which offers a lot of things to explore to support TEFL. It includes huge materials to browse such as printed, audio, and visual materials. YouTube is one of the most popular sites on the Internet which offers many authentic materials in the form of videos. These videos can be used in English classes in the purpose of boosting the students in spoken and in written skills which is also popular with Elearning (E-Learning in Youtube, 2013).

Further, writing is process of communication using conventional graphic system to convey a message to the reader. Setiyadi (2006) as cited in Supatmi (2010,p.12) says that writing is a ability in which we express ideas, feeling, and thoughts arranged in words, sentences and paragraph. It employs eyes, brain, and hand." Both researchers define writing as a process of expressing any written text in order to deliver specific messages to specific readers through serial pictures and youtubedownloaded-video as explained.

Serial Pictures is a set or series of photographs that are intended to tell a story or evoke a series of emotions in the viewers. A serial picture will often show pictures in deep emotional stages. It ranges from purely photographic works to photographs with captions or small notes to full text essays with a few or many accompanying photographs. It is assumed to be good for students. They will feel really enjoy in learning process because this media exposes pictures in series so they will write descriptive text easily and more enjoyable.

The You Tube Downloaded Video is a video which is downloaded from You Tube as video-sharing website. This website 
enable users to upload, view and share videos to any users over the unlimited users in the globe (History of Youtube, (2013). These videos can be achieved in a shorter time and can train students to be more active in speech and opinion as well as descriptive text writing.

Descriptive text is a text which describes a person, thing, place and certain condition in particular. According to Oshima and Hogue (2007,p.61) “descriptive writing appeals to the senses, so it tells how something looks, feels, smells, tastes, and or sounds." A good description is a word picture with which the readers can imagine the object, places, or person in his or her mind.

A descriptive usually follows a pattern of organization that is called spatial-order (Oshima and Hogue, 2006). Spatial-order is the arrangement of things in space which abnormal in the order of the words.

Above all propositions, the objective of the research are (1) To know the difference result of using YouTube Downloaded Video and Serial Pictures media toward writing ability in descriptive text at the seventh grades students of SMP N 2 Metro academic year 2012/2013, (2) To unlock which one is more effective of writing ability in descriptive text between learning by using YouTube Downloaded Video and Serial Pictures media at the seventh grade students of SMP N 2 Metro academic year 2012/2013. Several related studies are included accordingly.

\section{Methodology}

This research is quantitative research with specific research design true experimental design. The design is control group pre-test and post-test design (Sugiono, 2010) This quantitative research is aimed to determine the relationship between independent and dependent variable or outcome variable in sampling of a population.

Pre-test - Post-test Control Group Design:

\begin{tabular}{|l|c|c|c|}
\hline \multicolumn{1}{|c|}{ Group } & $\begin{array}{c}\text { Pre } \\
- \\
\text { test }\end{array}$ & $\begin{array}{c}\text { Treatmen } \\
\mathrm{t}\end{array}$ & $\begin{array}{c}\text { Post } \\
\text {-test }\end{array}$ \\
\hline $\begin{array}{l}(\mathrm{M})(\mathrm{R}) \\
\begin{array}{l}\text { Experimen } \\
\mathrm{t}\end{array}\end{array}$ & $\mathrm{T}-1$ & $\mathrm{X}_{1}$ & $\mathrm{~T}-2$ \\
\hline $\begin{array}{l}(\mathrm{M})(\mathrm{R}) \\
\text { Control }\end{array}$ & $\mathrm{T}-1$ & $\mathrm{X}_{2}$ & $\mathrm{~T}-2$ \\
\hline
\end{tabular}

(Karwono, 1992:77)

Notes :

$\mathrm{X}_{1} \quad$ : Treatment descriptive text using YouTube Downloaded Video

$\mathrm{X}_{2} \quad$ : $\quad$ Treatment descriptive text by Serial Pictures

$\mathrm{T}_{1} \quad$ : Pre- test, it will be given before treatment

$\mathrm{T}_{2} \quad$ : post- test, it will be given after the treatment
$\mathrm{R} \quad$ : Randomization
M : Matching

There are seven classes at the first grade of SMP N 2 Metro and each class in consist of 32 students, so the total number of population is 224 students. In general, the students' ability in English in each class is homogenous yet equal. However; the students in each class were divided into three categories; the high ability, the moderate ability and the low ability. Due to the fact above, both researchers take the sampling by using cluster random sampling because the members of 
sample are comparatively homogeneous. As a result two classes were chosen as real samples out of seven classes as the total populations. (Hatch and Farhady, 1982). The chosen samples were VII.1 and VII.2. Hence VII.1 class was as an experimental class and VII.2 class was as the control class. VII. 1 was treated with Serial Pictures and VII.2 was treated with You Tube downloaded video displayed respectively before writing.

The instruments were a set of tests; pre-test, and post-test. The pretest were administered to both experimental and control classes to know the students' writing ability in descriptive text. Both tests were a made by the teachers and were about different topics of animals, human, or things. All of the instruments were validated through several processes; content validity, construct validity through a judgment of the expert in writing, and split- half technique.

The post-test was given after the experimental and control classes were given the treatments to know the level of students about their writing ability in this research. The post-test scores were then compared with the pre-test to determine and find out the effectiveness of the given treatments. According to Karwono (2007) this design is suitable to use when the pre-test cannot be implemented or pre-tests had the possibility to influence the experimental treatment.

The researchers used Internal Consistency Reliability to judge the consistency of results across item (with Split Half) in the same test with the following formula :

$$
\mathrm{r}_{\mathrm{xy}}=\frac{\sum X Y}{\sqrt{\left(\sum x^{2}\right)\left(\sum y^{2}\right)}}
$$

Notes :

$\mathrm{r}_{\mathrm{xy}}=$ The coefficient correlation

between $\mathrm{X}$ variable and $\mathrm{Y}$ variable

$\mathrm{X}=$ The score of odd score

$\mathrm{Y}=$ The score of even score

$X^{2}=$ The quadrate score of the odd score

$y^{2} \quad=$ The quadrate score of the even score

$\sum X Y=$ The score of $\mathrm{X}$ and $\mathrm{Y}$ product

To find reliability of the test, the researcher used the Spearman Brown (Split Half) as the following formula.

$\mathrm{r}_{11}=\frac{2 x r_{x y}}{\left(1+r_{x y}\right)}$

(Arikunto, 2010,p. 223 )

Notes :

$\mathrm{r}_{11}$ : Reliability of instrument

$r_{x y}$ : correlation between score each split

\section{Finding and Discussion}

In reference to the theoretical research questions, theoretical framework and finding analysis of the data, it can be concluded that YouTube is more effective to improve descriptive text writing ability than Serial Pictures at the students even semester of seventh level in SMP 2 Metro academic year 2012/2013. The conclusion above can be seen by analysis data as follows and thus it answered the Research Question (2).

As described in the previous chapter, the purpose of this study was (1) to know the difference result of using YouTube Downloaded Video and Serial Pictures media 
toward students' writing ability in descriptive text instruction, and (2) to know which one is more effective of students' writing ability in descriptive text instruction between learning by YouTube Downloaded Video and Serial Pictures media. After a set of treatments and tests both researchers analyzed the average score of pretest and posttest for each class using YouTube Downloaded Video and Serial Pictures media compared to find out the difference of both scores.

The result of calculation on the value of the pretest and posttest score in each class showed that the distribution is normal. In addition, the calculation of t-test in experimental class, pretest showed that the probability is less than the level of significance $(0,05=2,04)$ Because the probability is less than the level of significance $(0,43<2,04)$ there is no difference and thus null hypothesis is accepted. For the calculation of posttest, it showed that the probability is higher than the level of significance $(3,96>2,04)$, there is difference and thus null hypothesis is rejected. This shows that there is any different result between pretest and posttest score in experimental class and control class.

In more detail, the change of students' posttest score is higher than their pretest value especially in experimental class which used YouTube Downloaded Video media. It means that, YouTube Downloaded Video media is more effective technique than Serial Pictures media to improve of students' writing ability in descriptive text instruction.

The results show that the posttest students in experimental class are better than control class. This can be seen when the posttest score of students compared with pretest score. In the experimental class the higest score was 90 and the lowest was 61 resulted the mean 74,20 and standard deviation 5,8. Meanwhile, in the control class the highest score was 77 and the lowest was 60 resulted the mean 69,4 and standar deviation 3,5. It was proved that the result of $t_{\text {test }}$, where $t_{\text {arith }}$ was 3,96 were higher than $t_{\text {table }}$ which was 2,04 on the criterion 0,05 .

The result indicates that there was significant differences between pretest and posttest score (posttest>pretest). This result is consistence with the result of the research by Savitrie (2011) implying that videos provided on YouTube are of different categories that can be used as materials for teaching English as long as they are suitable with the topic being taught. It was also found that the authentic videos used were chosen based on some important considerations, such as visualizations or imagery, the language use, the relevance of the videos to the topic and content, and the popularity of the content for most of the students. The videos were used for two major purposes; (1) to motivate the students at the beginning of the lesson (2) to introduce the topic, also for the main part of the lesson to facilitate the students to learn the topic.

Furthermore, the new information they got from the videos was able to arouse their curiosity as it encouraged them to actively involve themselves in the learning process. YouTube Downloaded Video media is effective to improve students' paragraph writing ability. With this media the students feel enjoy in learning descriptive text, so 
their achievement in descriptive text seemed to be improved.

The results are consistence with with the three former PayPal employees; Welton (2005) in Youtube (2013) which states that YouTube is a video-sharing website, on which users can upload, view and share videos. Students can enjoy writing descriptive text by watching these videos.

\section{Conclusion}

Having finished analyzed the theories, assumptions, and previous research findings, both researchers have come to conclusion that YouTube is more effective to improve descriptive text writing ability than Serial Pictures especially the students at even semester of seventh level in SMP 2 Metro academic year 2012/2013, with the following discrete propositions.

It means that students' writing ability in descriptive text will be higher if the teacher use YouTube Downloaded Video than Serial Pictures media in learning process.

This means that the hypothesis $\mathrm{Ha}$ in this research is accepted. Beside, the students enjoy and look fun in accepting information especially the new experience in learning of writing, while the teacher is easier in transferring material to the students.

Upon all, this study is consistent with the previous research conducted by Ahmad (2011), and Savitrie (2011) in that all techniques could improve the students' writing ability with discrete level of influence or improvements.

\section{Suggestion}

Looking back on the description above, the researchers would like to address some suggestions: (1) The students should be active and innovative when they follow the learning process, especially in learning of writing. YouTube Downloaded Video media (2) The researcher suggests that the English teacher can use YouTube Downloaded Video media to improve students' writing ability. (3).This research may encourage any researcher to conduct other studies concerning writing ability. Investigating other affecting factors is really needed to identify the problems and to develop the writing ability for the students and transferability of future research.

\section{References}

Ahmad, Ajis (2011). The Use of

Picture Series to Improve

Eight Graders' Writing

Descriptive Texts at MTs N

Babakan Ciledug Cirebon.

Malang:Unpublished thesis.

State University of Malang.

Arikunto, Suharsimi (2010).

Prosedur Penelitian

Qualitatif dan Kuantitatif.

Jakarta: Rineka Cipta

Audio Video (2013). retrieved on

Tuesday, $5^{\text {th }}$ February, 2013

fromhttp://w3.org/standards/

webdesign/audiovideo/html,

Brown, Douglas (2001). Teaching

by Principles: An Interactive

Approach to Language

Pedagogy, Second Edition.

California: Longman.

Broughton, Geoffrey et al. (2003).

Teaching English as a

Foreign Language $(2 r d)$.

Taylor \& France e-Library. 
E-learning (2013), retrieved on

Tuesday, $5^{\text {th }}$ February, 2013

http://mmursyidpw.com/e-

learning/kelas-maya-

mursyid/learning-descriptive-

text/descriptive-theory/

Hatch, Evelyn and Farhady, Hossein

(1982). Research Design and

Statistics for Applied

Linguistic.California:

Newbury House Publisher, Inc.

Harmer, Jeremy (2001). How to

Teach English: An

Introduction to the Practice

of English Language

Teaching. California:

Longman.

History of youtube (2013) retrieved

on Tuesday, $5^{\text {th }}$ February,

2013 from

http://www.youtube.com/t/ter $\mathrm{ms}$,

Karwono (1991). Jurnal Teknologi

Pembelajaran Teori dan

Penelitian: IKIP

Malang.

Karwono (2007). Pengaruh

Pemberian Umpan Balik dan

Locus of Control Terhadap

Kemampuan Mahasiswa

dalam Mengelola

Pembelajaran Mikro di FKIP

UM Metro.Universitas Negri

Jakarta.

Larsen-Freeman, Diane (2000).

Techniques and Principles in

Languages Teaching

$\left(2^{\text {nd }} E d\right)$. Oxford New York:

Oxford University Press.

Magno, Carlo (2009). Self-

Regulation and Approaches

to Learning in English

Composition Writing:

TESOL journal vol. 1, (1).

pp. 1-16.
Oshima,Alice and Hogue,Ann (2006)

Introduction to Academic English (3 rd Edition): Level

3. New York: Pearson Education, Inc.

Oshima, Alice and Hogue, Ann(2007) Writing Academic English (4 ${ }^{\text {th }}$ Edition). New York: Pearson Education, Inc.

Peha, Steve(2003).The Writing

Teacher's Strategy.

Longman. New York, USA.

Richards, Jack C, and Rodgers,

Theodore S (2001).

Approaches and Methods in

Languages Teaching.

Cambridge, MA: Cambridge

University Press.

Savitrie, Pramudhia (2011). The Use of Authentic Videos Taken

from YouTube in

the Teaching of English to the

Ninth Graders of SMPNegeri

12 Jember. Malang:

Unpublished thesis. State

University of Malang.

Sugiyono (2010). Metode Penelitian

Pendidikan Pendekatan

Kuantitatif, Kualitatif, dan $R$

\& D. Bandung: Alfabeta.

Setiyadi,Ag.B. (2006).Teaching

English as a foreign language.

Jakarta: CV. Graha Ilmu.

Welton (2005) in Youtube. Retrieved on Tuesday, $5^{\text {th }}$ February, 2013 from

http://www.youtube.com/han douts/youtubeineducation

Youtube in Education (2013) In

Youtube. Retrieved on Tuesday, $5^{\text {th }}$ February, 2013

from

http://techforschools.com/han douts/youtubeineducation 